\title{
Investigation of the Coincidence of Idiopathic Carpal Tunnel Syndrome and Ulnar Nerve Entrapment Neuropathy: Role of the Cutaneous Silent Period
}

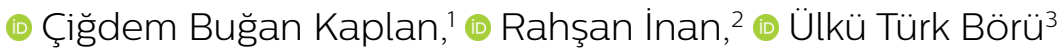

'Department of Neurology, Gebze Fatih State Hospital, Kocaeli, Turkey ${ }^{2}$ Department of Neurology University of Health Sciences Kartal Dr. Lütfi Kırdar Training and Research Hospital, İstanbul, Turkey ${ }^{3}$ Department of Neurology, Afyon Kocatepe University Faculty of Medicine, Afyon, Turkey

Submitted: 18.03.2019 Accepted: 22.06.2019

Correspondence: Rahşan İnan, Kartal Dr. Lütfi Kırdar Eğitim ve Araştırma Hastanesi, Nöroloji Kliniği, İstanbul, Turkey

E-mail: rahinan@yahoo.com

aprar

Keywords: Carpal tunnel syndrome; cutaneous silent period; ulnar nerve entrapment neuropathy.

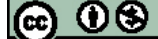

This work is licensed under a Creative Common Attribution-NonCommercial 4.0 International License.

\begin{abstract}
Objective: The aim of this study was to investigate the coincidence of ulnar nerve entrapment neuropathy in idiopathic carpal tunnel syndrome (CTS) patients and the role of the cutaneous silent period (CSP) technique in detecting this association.
\end{abstract}

Methods: A total of 42 patients referred to the Dr. Lutfi Kirdar Kartal Education and Research Hospital electromyography (EMG) laboratory with the initial diagnosis of carpal tunnel syndrome and 42 healthy age- and sex-matched volunteers were included in this cross-sectional study. Nerve conduction studies, needle EMG, and CSP measurement were performed on both groups.

Results: In the group of 42 patients, 10 were male and 32 were female, with a mean age of $42.68 \pm 7.25$ years, and the control group comprised 10 men and 32 women with a mean age of $35.58 \pm 8.35$ years. A total of 68 hands in the patient group and 78 hands in the control group were examined. In all, 16 hands had mild CTS, moderate CTS was present in 47 hands, and 5 hands demonstrated severe CTS. Ulnar nerve entrapment neuropathy was observed in 3 of the 42 patients. Prolonged median sensory and motor distal nerve latency, reduction of sensory and motor action potential amplitudes, and slowing of conduction velocity were observed in nerve conduction studies of the CTS group. Median CSP latency was prolonged in the CTS group $(p=0.000)$. Changes in median CSP duration and ulnar CSP latency and duration did not reach the level of statistical significance $(p>0.05)$. There was no correlation between the severity of CTS and ulnar nerve entrapment neuropathy coincidence with the latency and duration of CSP.

Conclusion: To the best of our knowledge, no previous study investigating ulnar CSP changes in CTS patients has been reported in the literature. The results of this research indicated that while CSP changes were detected in the CTS patients, CSP changes were not associated with the severity of CTS. There was no significant change in CSP parameters in patients with CTS and ulnar nerve entrapment neuropathy in the wrist.

\section{INTRODUCTION}

Idiopathic carpal tunnel syndrome (CTS) is the most common form of median nerve lesions caused by compression of the median nerve as it passes through the carpal tunnel. ${ }^{[1-3]}$ Symptoms in CTS patients usually occur as numbness and weakness in the first three fingers, while in some patients the symptoms may spread to all fingers. Due to the anatomical proximity of the carpal tunnel and the Guyon canal, the high pressure in the carpal tunnel can indirectly compress the ulnar nerve fibers, suggesting that the ulnar nerve may also be trapped in the wrist along with the median nerve. ${ }^{[4-6]}$ Cooccurence of the CTS and ulnar nerve entrapment was reported by Sedal et al. ${ }^{[7]}$ for the first time and they reported ulnar nerve entrapment incidence as $44 \%, 39 \%$ decrease in ulnar nerve sensory action potential, and $4.8 \%$ prolongation in distal sensory latency. Vahdatpour et al. ${ }^{[8]}$ and Gozke et al. ${ }^{[5]}$ reported this rate as $9.7 \%$ and $18.4 \%$, respectively. With standard nerve conduction studies, the abnormalities in thick myelinated fibers can be detected. Although nerve conduction studies are the most sensitive method in the diagnosis of CTS, the severity of symptoms and abnormalities in findings are not parallel in some patients. This difference between clinical findings and nerve conduction studies suggests that fine fiber involvement causes this 
condition. Cutaneous silent period (CSP), which is one of the methods used to demonstrate fine fiber involvement, unlike other methods, is a method that is noninvasive, does not require any specific equipments and can be measured with an EMG device done for standard nerve conduction studies, and shows no additional cost to the patient. ${ }^{[9]}$

While there are studies in the literature on changes in the median nerve CSP in CTS patients, no studies of CSP on the ulnar nerve in the same hand have been reported. The primary aim of this study was to determine the cooccurence of ulnar nerve-entrapment neuropathy in patients diagnosed clinically and electrophysiologically with idiopathic CTS, and to investigate the diagnostic value of the changes in CSP parameters of the median and ulnar nerve in CTS.

\section{MATERIALS AND METHODS}

This study was performed on 42 patients who were diagnosed with idiopathic CTS in our EMG laboratory between June 2014 and August 2014, and 42 healthy volunteers with age and sex matched. The results of the study performed on the hands of the 68 patients and 78 healthy volunteers were evaluated.

This cross-sectional, descriptive, controlled study was planned by the Scientific Research and Evaluation Board of our hospital on $06 / 03 / 2014$ and approved with protocol number $895 / 3307 / 1009 / 283$. The patients were informed about the study and informed consent form was obtained.

The criteria for inclusion in the study were clinically and electrophysiologically diagnosed as idiopathic CTS, agreeing to participate in the study and being older than 20 years. Patients with muscle and nerve diseases, endocrine, metabolic and systemic diseases, pregnant women, patients with cervical radiculopathy and history of CTS and cervical disc herniation operation were excluded from the study.

Boston Carpal Tunnel Questionnaire, Boston Symptom Severity and Boston Functional Capacity Scales were used to determine the clinical symptoms of the patients. Visual Analogue Scale (VAS) was used to determine the severity of the pain.

\section{Electroneurophysiological examination}

Nerve conduction and needle EMG examinations

Electrophysiological examinations were performed using a 2-channel EMG instrument (Nihon-Kohden). Nerve conduction and CSP examinations and needle electromyography (EMG) examinations were performed by the same investigator when the subjects were in the supine position. The electrophysiological studies studied in the patients were as following: Median, ulnar and dorsalulnarcutaneous sensory nerve and standard nerve conduction examina- tions of the median and ulnarmotor nerves (distallatances, sensory and motor action potential amplitudes and conduction rates), median and ulnar $F$ responses, concentric needle EMG examinations in abductor pollicis brevis (APB) and adductor digiti minimi (ADM) muscles. Patients with idiopathic CTS were classified as mild, moderate and advanced CTS according to the evaluation criteria of our laboratory.

- Mild CTS: prolongation of median sensory distal latency (>3.2 ms), slowing of sensory conduction rate $(<45 \mathrm{~m} / \mathrm{s})$, or lower sensory potential amplitude below normal

- Moderate CTS: In addition to mild CTS, median nerve distal motor latency prolongation (>4.2 ms), decreased median motor response amplitude (2.5-5mv)

- Advanced CTS: Loss of median sensory response and severe decrease or loss in median motor response amplitude $(<2.5 \mathrm{mv})$.

\section{Cutaneous silent period}

For CSP, a ring electrode was put on the 2 nd and 5 th fingers on the upper extremity and a stimulation with a duration of $0.3 \mathrm{~ms}$ and intensity of 15 times of the sensory threshold was given. CSP responses were obtained from the APB muscle with the stimulation of the 2 nd finger and ADM muscle with the stimulation of the 5 th finger. Five consecutive responses were averaged and rectified. The start and end points of the silent period were determined as the sites where the electromyographic activity suddenly stopped and appeared again.

\section{Statistical analysis}

SPSS (Statistical Package for Social Sciences) 20.0 for Windows program was used in the evaluation of the findings.

Chi-square test was used to compare the qualitative data such as age and gender. Independent samples t test was used for comparison of the patient and control groups, Kruskall Wallis test was used for comparison of subgroups according to CTS grade (mild-medium-advanced) and Mann-Whitney $U$ test was used for comparison of CTS patients with and without ulnar nerve involvement.

Results were given as mean \pm standard deviation, and $\mathrm{P}<0.05$ was considered as statistically significant.

\section{RESULTS}

\section{Demographic features}

42 patients ( $10 \mathrm{M}, 32 \mathrm{~F})$ with a mean age of $42.68 \pm 7.25$ years and 42 healthy volunteers ( $10 \mathrm{M}, 32 \mathrm{~F})$ with a mean age of $35.58 \pm 8.35$ years were included in the study. In the patient group, 68 hands and in the control group, 78 hands were examined. 26 patients (62\%) had bilateral and 16 patients (38\%) had unilateral CTS. CTS was mild in 16 hands (23.5\%), moderate in 47 hands (69.1\%), and severe in 5 hands $(7.4 \%)$. 
Table I. Median nerve conduction changes in patient and control groups

\begin{tabular}{lccc}
\hline & Patient & Control & p \\
\hline Median sensory speed & $34.48 I \pm 4.9282$ & $52.131 \pm 5.5163$ & 0.000 \\
Median sensory latency & $3.6294 \pm 0.50346$ & $2.4053 \pm 0.18928$ & 0.000 \\
Median sensory amplitude & $13.537 \pm 6.8781$ & $30.849 \pm 9.6760$ & 0.000 \\
Median motor speed & $56.201 \pm 6.4958$ & $62.972 \pm 4.8534$ & 0.000 \\
Median motor latency & $4.7468 \pm 1.38513$ & $2.8131 \pm 0.29902$ & 0.000 \\
Median motor amplitude & $11.8578 \pm 4.43648$ & $13.0553 \pm 4.51978$ & 0.109 \\
\hline
\end{tabular}

Table 2. CSP changes in patient and control groups

\begin{tabular}{lccc}
\hline & Patient & Control & p \\
\hline Median CSP latency & $79.326 \pm 7.5534$ & $72.374 \pm 6.7723$ & 0.000 \\
Median CSP duration & $45.847 \pm 10.1187$ & $43.451 \pm 8.7929$ & 0.128 \\
Ulnar CSP latency & $77.056 \pm 7.2094$ & $75.015 \pm 6.7355$ & 0.079 \\
Ulnar CSP duration & $38.885 \pm 7.9173$ & $39.868 \pm 7.6808$ & 0.448 \\
\hline CSP: Cutaneous silent period. & & &
\end{tabular}

The mean Boston Symptom Scale was 34.99 \pm 8.271 (mild 35.56 \pm 11.302 , moderate 35.09 \pm 7.138 , advanced 32.2 \pm 8.349 ), and the Boston Functional Capacity Scale average was $18,81 \pm 6,809$ (mild $15.94 \pm 7.132$, moderate 19.62 \pm 6.559 , advanced $20.4 \pm 6.877$ ). There was no correlation between scale scores and CTS grade $(p>0.05)$.

The mean VAS score was 4.24 \pm 1.62 . Although there was an increase in VAS score according to CTS grade, no statistically significant difference was found $(p=0.758)$.

Nerve conduction and needle EMG examination findings

In the CTS group, prolongation of the latency in median sensory and motor nerve responses, decrease in response amplitudes and slowing of conduction rates were detected (Table I).

Median $\mathrm{F}$ response latency was found to be longer in CTS patients than in the control group $(27.73 \pm 2.57$ msec; $24.78 \pm 1.64 \mathrm{msec})(p=0.000)$. Median $F$ response could not be obtained in one patient with advanced CTS. FTS latency was prolonged as the CTS grade increased $(p=0.000)$.

No statistically significant correlation was found between Ulnar $\mathrm{F}$ latencies between patient and control groups and according to CTS grade $(p=0.683 ; p=0.757)$.

Needle EMG examinations revealed chronic neurogenic involvement $(2.94 \%)$ in bilateral APB muscles of the same patient, one of which had moderate and one advanced CTS without spontaneous denervation.

Of the 42 patients, 3 (7.14\%) of whom had moderate CTS ( 3 of 68 hands $(4.41 \%)$ ) had concurrent ulnar entrapment neuropathy on the wrist. One patient had low amplitude in ulnar sensory response (8 microvolts), one patient had prolongation in ulnar sensory distal latency $(2.74 \mathrm{~ms})$, and one patient had prolongation in ulnar sensory and motor distal latency $(2.8 ; 4.54 \mathrm{~ms})$. No abnormalities were ob-

Table 3. CSP changes according to CTS grade

\begin{tabular}{lcccr}
\hline & Mild & Moderate & Advanced & p \\
\hline Median CSP latency & $78.675 \pm 6.7183$ & $78.962 \pm 7.6283$ & $84.840 \pm 8.7148$ & 0.417 \\
Median CSP duration & $43.450 \pm 9.7254$ & $46.706 \pm 10.3205$ & $45.440 \pm 10.1759$ & 0.547 \\
Ulnar CSP latency & $77.188 \pm 7.9845$ & $77.379 \pm 6.8581$ & $73.600 \pm 8.6267$ & 0.598 \\
Ulnar CSP duration & $35.950 \pm 7.8532$ & $39.272 \pm 7.9136$ & $44.640 \pm 4.5682$ & 0.055 \\
\hline
\end{tabular}

CSP: Cutaneous silent period; CTS: Carpal tunnel syndrome.

Table 4. CSP changes in CTS patients with and without ulnar involvement

\begin{tabular}{lccr}
\hline & Ulnar Involvement (+) & Ulnar Involvement (-) & p \\
\hline Median CSP latency & $75.133 \pm 6.7211$ & $79.520 \pm 7.5799$ & 0.311 \\
Median CSP duration & $51.867 \pm 8.4388$ & $45.569 \pm 10.1580$ & 0.258 \\
Ulnar CSP latency & $83.133 \pm 12.4777$ & $76.775 \pm 6.9091$ & 0.475 \\
Ulnar CSP duration & $35.467 \pm 6.3571$ & $39.043 \pm 7.9866$ & 0.439 \\
\hline
\end{tabular}

CSP: Cutaneous silent period; CTS: Carpal tunnel syndrome. 
served in the motor responses and needle EMG findings of the muscles with ulnar nerve innervation. None of the 5 patients with advanced CTS showed conduction changes in the ulnar nerve. Moderate CTS was detected in $3 \mathrm{pa-}$ tients with ulnar nerve conduction changes.

\section{Findings in cutaneous silent period changes}

Median CSP latency was found to be long in the CTS group $(p=0.000)$. Median CSP duration and ulnar CSP latency and duration changes were not statistically significant $(p>0.05)$ (Table 2). No correlation was found between the CTS grade and median and ulnar CSP latency and duration ( $p>0.05)$ (Table 3).

There was no significant difference between the median and ulnar CSP latency and duration in CTS patients with and without ulnar nerve involvement $(p>0.05)$ (Table 4).

\section{DISCUSSION}

In this study we investigated concurrent ulnar nerve entrapment neuropathy and the utility of CSP for diagnostic purposes in idiopathic CTS patients. The results of this study were as following: In 3 of 42 CTS patients (7.14\%) concurrent ulnar nerve entrapment was detected in the wrist. The most statistically significant finding regarding CSP parameters was longer median CSP latency in the patient group compared to the control group $(p=0.000)$. The changes observed in the median CSP duration and ulnar CSP latency and durations were not significant.

Due to the anatomical proximity of the carpal tunnel and the Guyon canals, it was found that the increase in the pressure in the carpal tunnel caused mechanical traction in the transverse carpal ligament, causing volumetric and pressure changes in the Guyon canal..$^{[8]}$ Concurrent ulnar tunnel syndrome can be detected in approximately $\mathrm{I} / 3$ of CTS patients. It was reported that after carpal tunnel release surgeries, in approximately $90 \%$ of these patients, ulnar symptoms decreased and no operation was required for ulnar entrapment neuropathy due to the changes in the structure and volume of carpal and ulnar ducts. ${ }^{[0]}$ Vahdatpour et al. ${ }^{[8]}$ reported that ulnar nerve involvement in CTS patients was $9.7 \%$. In $43 \%$ of these patients, entrapment was found at the wrist level ( $4.2 \%$ of all patients). Correlation between the grade of CTS and ulnar nerve involvement was shown. While ulnar nerve entrapment rate was $7.5 \%$ in moderate CTS patients, this rate increased to $12.5 \%$ in advanced CTS patients. In our study, the coexistence of median and ulnar nerve entrapment neuropathy was found to be $7.14 \%$ in accordance with the literature. Latency and amplitude changes of ulnar sensory nerve were observed in these patients. However, unlike the literature, we did not find a relationship between the degree of CTS and ulnar nerve involvement. Moderate CTS was detected in three patients with ulnar nerve involvement, and no ulnar nerve involvement was observed in any of the advanced CTS patients. In a study by Gozke et al.,.[5] the association of CTS and ulnar entrapment neuropathy was reported as
$18.4 \%$ and it was reported to be more frequent especially in moderate-advanced CTS patients. In these patients, the most common finding was reported to be prolongation of ulnar sensory nerve distal latency, and ulnar motor nerve conduction studies were found to be normal.

In our study, we did not find a significant relationship between CTS grade and silent period latency and time changes. The only statistically significant finding was prolonged median CSP latency in the patient group. Median CSP duration and ulnar CSP latency and changes in duration were not statistically significant. Different results have been reported in the literature. Koo et al. ${ }^{[9]}$ have found the median CSP latency significantly longer in the CTS group, but have not observed a significant difference in duration. Aurora et al. ${ }^{[1]}$, and Yaman et al..$^{[12]}$ reported that they did not detect a significant difference in silent period latencies compared to the control group. Aurora et al. ${ }^{\left[{ }^{[1]}\right]}$ and Svilpauskaite et al. ${ }^{[13]}$ reported that the duration of CSP was prolonged in mild and moderate CTS patients and that CSP could not be obtained in advanced CTS cases, while some studies showed that CTS grade was not associated with silent period changes. ${ }^{[14]}$

To the best of our knowledge, this study is original because no ulnar CSP changes have been studied in CTS patients. However, we did not find any significant changes in ulnar CSP parameters in CTS patients with and without ulnar nerve involvement. Although CSP is a useful test for evaluating the function of fine fibers (A delta), it has not been found to be a reliable diagnostic method to use with routine nerve conduction investigations in entrapment neuropathies. In another aspect, we can argue that there is no absence of fine fiber involvement in entrapment neuropathies due to the absence of a significant disturbance in the silent period parameters, but silent period studies are needed in larger patient series to confirm this hypothesis.

\section{Ethics Committee Approval}

This cross-sectional, descriptive, controlled study was planned by the Scientific Research and Evaluation Board of our hospital on 06/03/2014 and approved with protocol number $895 / 3307 / 1009 / 283$.

Informed Consent

Prospective study.

Peer-review

Internally peer-reviewed.

Authorship Contributions

Concept: Ç.B.K., R.I.., Ü.T.B.; Design: Ç.B.K., R.I.., Ü.T.B.; Supervision: Ç.B.K., R.I., Ü.T.B.; Fundings: Ç.B.K., R.i., Ü.T.B.; Materials: Ç.B.K., R.I., Ü.T.B.; Data: Ç.B.K., R.I.,, Ü.T.B.; Analysis: Ç.B.K., R.I., Ü.T.B.; Literature search: Ç.B.K., R.I., Ü.T.B.; Writing: Ç.B.K., R.I., Ü.T.B.; Critical revision: Ç.B.K., R.I.,, Ü.T.B.

Conflict of Interest

None declared. 


\section{REFERENCES}

1. Mumenthaler M, Stöhr M, Müler-Vahl H. Türk-Börü Ü (Çeviri editörü). Omuz ve kol bölgesinin tek sinir lezyonları. Periferik sinir lezyonları ve radiküler sendromlar. İstanbul: Nobel Tip kitabevleri, 2005:224-319.

2. Bengston KA, Brault JS. Hand Disorders. In: Delisa J A. Physical Medicine \& Rehabilitation Principles and Practice. 3th Ed. USA: Lippincott Williams \& Wilkins, 2005:843-54.

3. Ertekin C. Santral ve Periferik EMG Anatomi-Fizyoloji-Klinik. İzmir: Meta Basım Matbaacılık, 2006:387-453.

4. Tamburin S, Cacciatori C, Praitano ML, Marani S, Zanette G. Ulnar nerve impairment at the wrist does not contribute to extramedian sensory symptoms in carpal tunnel syndrome. Clin Neurophysiol 2009;120:1687-92. [CrossRef]

5. Gozke E, Dortcan N, Kocer A, Cetinkaya M, Akyuz G, Us O. Ulnar nerve entrapment at wrist associated with carpal tunnel syndrome. Neurophysiol Clin 2003;33:219-22. [CrossRef]

6. Ginanneschi F, Milani P, Mondelli M, Dominici F, Biasella A, Rossi A. Ulnar sensory nerve impairment at the wrist in carpal tunnel syndrome. Muscle Nerve 2008;37:183-9. [CrossRef]

7. Sedal L, McLeod JG, Walsh JC. Ulnar nerve lesions associated with the carpal tunnel syndrome. J Neurol Neurosurg Psychiatry 1973;36:118-23.

8. Vahdatpour B, Raissi GR, Hollisaz MT. Study of the ulnar nerve compromise at the wrist of patients with carpal tunnel syndrome. Electromyogr Clin Neurophysiol 2007;47:183-6.

9. Koo YS, Park HR, Joo BE, Choi JY, Jung KY, Park KW, et al. Utility of the cutaneous silent period in the evaluation of carpal tunnel syndrome. Clin Neurophysiol. 2010;121:1584-88. [CrossRef]

10. Waugh RP, Pellegrini VD. Ulnar tunnel syndrome. Hand Clin 2007;23:301-10. [CrossRef]

11. Aurora SK, Ahmad BK, Aurora TK. Silent period abnormalities in carpal tunnel syndrome. Muscle Nerve 1998;21:1213-5. [CrossRef]

12. Yaman M, Uluduz D, Solak O, Pay G, Kiziltan ME. The cutaneous silent period in carpal tunnel syndrome. Electromyogr Clin Neurophysiol 2007;47:215-20.

13. Svilpauskaite J, Truffert A, Vaiciene N, Magistris MR. Electrophysiology of small peripheral nerve fibers in man. A study using the cutaneous silent period. Medicina (Kaunas) 2006;42:300-13.

14. Resende LA, Alves RP, Castro HA, Kimaid PA, Fortinguerra CR, Schelp AO. Silent period in carpal tunnel syndrome. Electromyogr Clin Neurophysiol 2000;40:31-6.

\section{İdiopatik Karpal Tünel Sendromu Hastalarında Ulnar Sinir Tuzak Nöropati Birlikteliğinin Araştırılması: Kutanöz Sessiz Periyodun Rolü}

Amaç: Bu çalışmada idiyopatik karpal tünel sendromu (KTS) hastalarında ulnar sinir tuzak nöropati birlikteliği ve bu birlikteliği saptamada kutanöz sessiz periyodun (KSP) rolünün araştırılması amaçlandı.

Gereç ve Yöntem: Bu çalışmada kesitsel olarak Dr. Lütfi Kırdar Kartal Eğitim ve Araştırma Hastanesi EMG Laboratuvarı'na KTS ön tanısı ile yönlendirilen 42 hasta ile yaş ve cinsiyet açısından eşleşen 42 sağıklı gönüllüde sinir ileti incelemeleri, iğne elektromiyografi ve KSP ölçümleri yapıldı.

Bulgular: Çalışmaya yaş ortalaması $42.68 \pm 7.25$ yıl olan 42 hasta ( 10 erkek, 32 kadın) ve yaş ortalaması 35,58 $\pm 8,35$ yıl olan 42 sağlıklı gönüllü ( 10 erkek, 32 kadın) dahil edildi. Hasta grubunda 68, kontrol grubunda 78 elde incelemeler yapıldı. On altı elde hafif, 47 elde orta, beş elde ileri derecede KTS saptandı. Kırk iki hastadan üçünde eş zamanlı ulnar sinir tuzak nöropatisi saptandı. Sinir ileti incelemelerinde KTS grubunda medyan duyusal ve motor sinir yanıtlarında latanslarda uzama, yanıt amplitüdlerinde düşme ve ileti hızlarında yavaşlama izlendi. KTS grubunda medyan KSP latansı uzun bulundu $(p=0.000)$. Medyan KSP süre ve ulnar KSP latans ve süre değişiklikleri istatistiksel olarak anlamlı bulunmadı ( $p>0.05$ ). KTS derecesi ve ulnar sinir tuzak nöropatisi olup olmaması ile KSP latans ve süresi arasında ilişki saptanamadı.

Sonuç: Literatürde KTS hastalarında ulnar KSP değişikliklerini araştıran bir çalışma bildirilmemiştir. Bu çalışmada KTS’de KSP değişikliklerinin saptandığı fakat KTS derecesi ile KSP değişikliklerinin ilişkili olmadığı gösterildi. KTS ile birlikte el bileğinde ulnar sinir tuzak nöropatisi olan hastalarda KSP parametrelerinde anlamlı değişiklik saptanmadı.

Anahtar Sözcükler: Karpal tünel sendromu; kutanöz sessiz periyod; ulnar sinir tuzak nöropati. 